\title{
ТЯЖЕЛЫЕ МЕТАЛЛЫ В ПРИБРЕЖНЫХ ДОННЫХ ОСАДКАХ И ВОДОРОСЛЯХ ВОСТОЧНОЙ ЧАСТИ ФИНСКОГО ЗАЛИВА
}

\author{
Левит Р.Л., Кудрявцева В.А., Шигаева Т.Д.
}

ФГБУН «Санкт- Петербургский Федеральный исследовательский центр Российской академии наук», Санкт-Петербург, Россия

Санкт-Петербургский научно-исследовательский центр экологической безопасности РАН,

$$
\begin{gathered}
\text { Санкт-Петербург, Россия } \\
\text { valenkud@yandex.ru }
\end{gathered}
$$

DOI: 10.26902/ASFE-11_166

Восточная часть Финского залива испытывает большое антропогенное воздействие изза загрязняющих веществ, поступающих с водосборного бассейна (прежде всего со стоком Невы). Дополнительную опасность для прибрежной зоны представляют действующие и строящиеся портовые комплексы, нефтяные терминалы, очистные сооружения, дамба, гидротехнические работы, крупнотоннажное судоходство.

В течение ряда лет (2014-2019 гг.) проводили комплексное исследование прибрежной зоны залива, в ходе которого определяли валовые концентрации $\mathrm{Zn}, \mathrm{Cd}, \mathrm{Pb}, \mathrm{Cu}, \mathrm{Fe}, \mathrm{Mn}, \mathrm{Al}$ и $\mathrm{P}$ в поверхностных слоях донных осадков (ДО) и воде, концентрации подвижных форм тяжелых металлов (ТМ), а также концентрации ТМ в водорослях. Анализы ТМ выполняли методами масс-спектрометрии с индуктивно-связанной плазмой и инверсионной вольтамперометрии.

Образцы ДО и воды отбирали на 14 станциях, расположенных на северной и южной сторонах Финского залива от Выборга до Лужской губы. Гранулометрический анализ показал, что ДО в основном состоят из песчаных фракций, содержание органического вещества - 0,2$0,8 \%$, глинистых фракций - менее $6 \%$. Донным осадкам свойственна низкая сорбционная способность по отношению к ТМ (менее 10 мкмоль/г), что предопределяет высокую вероятность вторичного загрязнения воды. Уровни загрязнения ДО металлами в 2019 году (в мкг/г): Zn (10-30) > Pb (5-20) > Cu (3-10) >> Cd (0,05-0,3). По сравнению с 2014 г. загрязнение осадков $\mathrm{Zn}$ и $\mathrm{Cu}$ снизилось, а $\mathrm{Pb}$ и $\mathrm{Cd}-$ сохранилось на прежнем уровне. На основании корреляционных связей между элементами можно предположить, что основные источники загрязнения ДО связаны с береговой эрозией, ливневыми стоками, разложением водорослей. Расчеты экологических критериев показали, что экологическая опасность ДО, обусловленная аккумуляцией ТМ, в настоящее время относительно невысока, однако, если процесс накопления ТМ продолжится, токсические эффекты могут проявиться, причем более уязвимыми являются водные экосистемы южного побережья залива. Вклады отдельных элементов в общую экологическую опасность ТМ в донных осадках образовали ряд: Zn (3\%) $<\mathrm{Pb}(6 \%)<\mathrm{Cu}(11 \%)<<\mathrm{Cd}(80 \%)$, откуда следует, что накопление Сd осадками представляет высокую угрозу экологической безопасности водоемов.

Анализ концентраций ТМ в водорослях Cladophora glomerata, Ulva intestinalis, Fucus vesiculosus, отобранных в местах разрастания, показал, что водоросли активно поглощают ионы металлов из водной среды и активность поглощения зависит от природы элемента и вида водорослей. Сорбционные способности высушенных водорослей составляют 30-300 мкмоль/г, что значительно выше сорбционных способностей ДО. Таким образом, в местах с высокой биопродуктивностью могут наблюдаться дополнительное накопление металлов в ДО и возникновение очагов загрязнения прибрежных вод из-за гипоксии и выхода металлов из разлагающейся биомассы. Так как концентрации ТМ в водорослях отражают общую картину загрязнения водоема биодоступными формами металлов, целесообразно использовать водоросли в программах экологического мониторинга. 